\title{
Atmosphere and hydrological controls of the evapotranspiration over a floodplain forest in the Bananal Island region, Amazonia
}

\author{
L. S. Borma, ${ }^{1}$ H. R. da Rocha, ${ }^{1}$ O. M. Cabral, ${ }^{2}$ C. von Randow, ${ }^{3}$ E. Collicchio, ${ }^{4}$ \\ D. Kurzatkowski, ${ }^{5}$ P. J. Brugger, ${ }^{5}$ H. Freitas, ${ }^{1}$ R. Tannus, ${ }^{1}$ L. Oliveira, ${ }^{1}$ C. D. Rennó, ${ }^{3}$ \\ and P. Artaxo ${ }^{1}$ \\ Received 30 October 2007; revised 15 September 2008; accepted 27 October 2008; published 20 January 2009.
}

[1] This article discusses seasonal and interannual variations of the evapotranspiration (ET) rates in Bananal Island floodplain, Brazil. Measurements included ET and sensible heat flux using the eddy covariance method, atmospheric forcings (net radiation, Rn, vapor pressure deficit, VPD, wind speed and air temperature), soil moisture profiles, groundwater level and flood height, taken from November 2003 to December 2006. For the hydrological years (October-September) of 2003/2004, 2004/2005 and 2005/2006, the accumulated precipitation was 1692, 1471, $1914 \mathrm{~mm}$ and the accumulated ET was 1361, 1318 and $1317 \mathrm{~mm}$, respectively. Seasonal analyses indicated that ET decreased in the dry season (average $3.7 \mathrm{~mm}_{\text {day }}{ }^{-1}$ ), despite the simultaneous increase in $\mathrm{Rn}$, air temperature and VPD. The increase of ET in the wet season and particularly in the flood period (average $4.1 \mathrm{~mm} \mathrm{day}^{-1}$ ) showed that the free water surface evaporation strongly influenced the energy exchange. Soil moisture, which was substantially depleted during the dry season, and adaptative vegetation mechanisms such as leaf senescence contributed to limit the dry season ET. Strong drainage within permeable sandy soils helped to explain the soil moisture depletion. These results suggest that the Bananal flooding area shows a different pattern in relation to the upland Amazon forests, being more similar to the savanna strictu senso areas in central Brazil. For example, seasonal ET variation was not in phase with Rn; the wet season ET was higher than the dry season ET; and the system stored only a tiny memory of the flooding period, being sensitive to extended drought periods.

Citation: Borma, L. S., et al. (2009), Atmosphere and hydrological controls of the evapotranspiration over a floodplain forest in the Bananal Island region, Amazonia, J. Geophys. Res., 114, G01003, doi:10.1029/2007JG000641.

\section{Introduction}

[2] One of the main goals of the Large-scale BiosphereAtmosphere Experiment in Amazonia (LBA) is to describe the controls, and the temporal and spatial variability of evapotranspiration (ET) in the Amazon basin. Pioneer studies of Shuttleworth [1988] showed that the ET over a tropical forest in central Amazonia (Manaus) was about $3.5 \mathrm{~mm}$ day $^{-1}$ and increased in the dry season, concurrently with the net radiation. More recent measurements in other Amazonian forests corroborated that a lack of water stress over terra firme tropical humid forest during the dry season can explain higher ET values during the dry spells than in

\footnotetext{
${ }^{1}$ Escola de Artes, Ciências e Humanidades, Universidade de São Paulo, São Paulo, Brazil.

${ }^{2}$ Embrapa Meio Ambiente, Jaguariuna, São Paulo, Brazil.

${ }^{3}$ Instituto Nacional de Pesquisas Espaciais, Cachoeira Paulista, São Paulo, Brazil.

${ }^{4}$ Fundação Universidade do Tocantins - UNITINS, Palmas, Tocantins, Brazil.

${ }^{5}$ Universidade Federal do Tocantins, Palmas, Tocantins, Brazil.

Copyright 2009 by the American Geophysical Union. 0148-0227/09/2007JG000641
}

the wet season [Sommer et al., 2002; da Rocha et al., 2004, 2009; von Randow et al., 2004; Souza-Filho et al., 2005]. According to Negrón-Juarez et al. [2007], ET values at Amazon sites varied from $3.8 \pm 0.6$ to $4.3 \pm 0.9 \mathrm{~mm}$ day $^{-1}$ during the dry season and from $2.5 \pm 0.4$ to $4.1 \pm 0.4 \mathrm{~mm}$ day $^{-1}$ during the wet season. The authors found that the net surface radiation was the main driver of ET and that the dry season ET was influenced by the amount of soil moisture stored in the preceding wet season rather than by rainfall events occurring during the current dry season. Conversely, over transitional forests and savannas in Amazonia, the dry season ET was substantially reduced compared to the wet season ET. This has been attributed to a longer dry season length, lower annual precipitation rates and, consequently, lower soil moisture storage to sustain high ET rates [ da Rocha et al., 2009].

[3] The ability of the Amazonian evergreen forests to maintain high ET, despite an extended dry season, has been attributed to a deep root system and mechanisms of hydrological distribution [da Rocha et al., 2004; Oliveira et al., 2005; Bruno et al., 2006; Hodnett et al., 1997] which, in response to an increase of sunlight (due to decreased cloudiness), enhance ET rates and photosynthetic capacity 

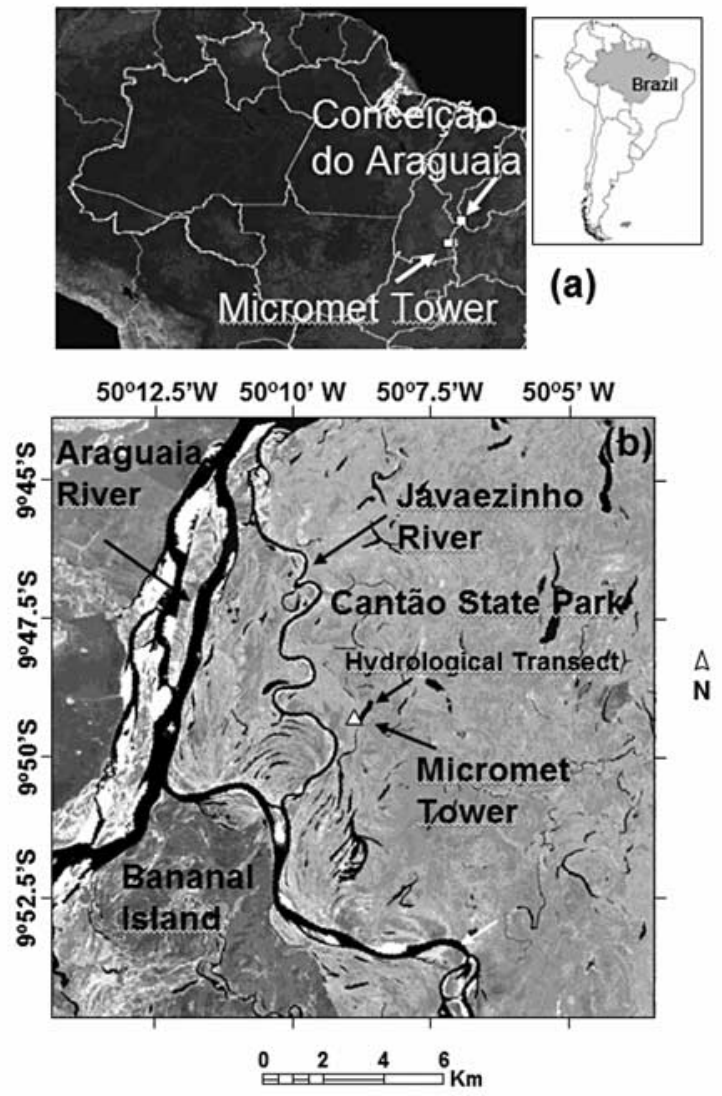

(c)
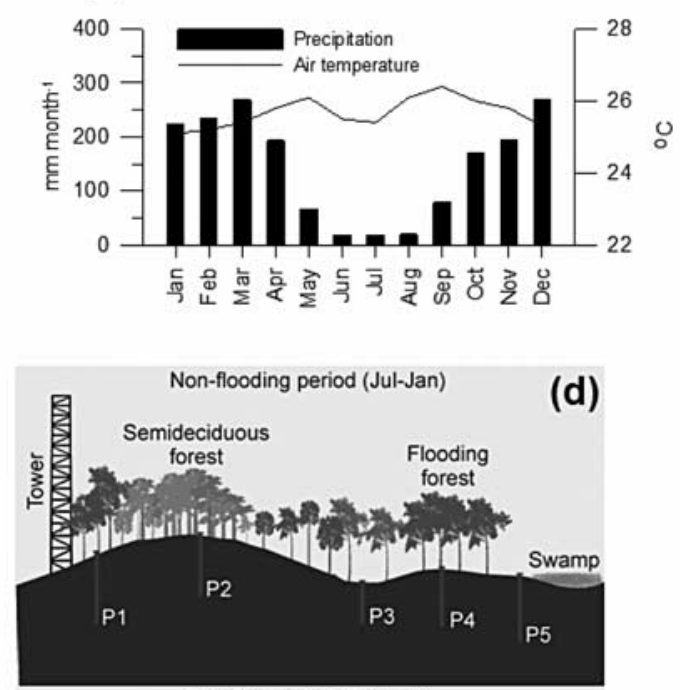

Flooding period (Feb-Jun)

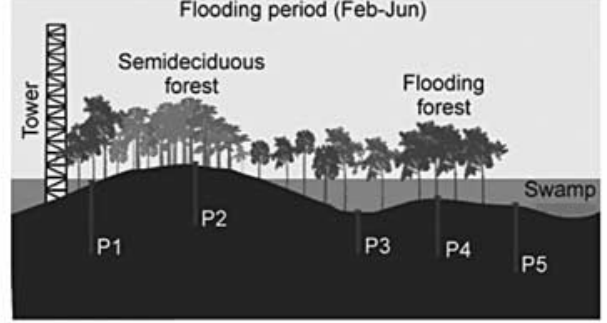

Figure 1. (a) Legal Amazonia map and location of the Javaezinho micrometeorological tower and Conceição do Araguaia climatological station. (b) Cantão State Park and indication of Bananal Island, main rivers in the Park and micrometeorological tower. (c) Monthly mean temperature $\left({ }^{\circ} \mathrm{C}\right)$ and precipitation (mm) observed in 1975-1998 in Conceição do Araguaia Station $\left(8^{\circ} 15^{\prime} 16^{\prime \prime}\right.$ e $\left.49^{\circ} 15^{\prime} 47^{\prime \prime}\right)$. Source: Instituto Nacional de Meteorologia, Brazil. (d) Hydrological transect during the non-flooding period (July-January) and the flooding period (February-June).

during the dry season [Goulden et al., 2004, Saleska et al., 2007].

[4] These studies have significantly improved the understanding of the ET controls over different sites in the Amazon forest. However, there is a noticeable lack of information about the seasonality and controls of ET over floodplain areas in Amazonia. Upland areas with terra firme forests are most common in the basin, but the riverine floodplains and other wetlands are also composed of substantial features of the region, composing roughly $17 \%$ of a investigated area of 1.8 million $\mathrm{km}^{2}$ of the entire Amazon basin [Hess et al., 2003].

[5] This article focus on seasonal and interannual variations of ET rates in a seasonal floodplain area dominated by savanna vegetation type, in the South-eastern boundary of Amazonia, near the Bananal Island. The analysis is based on eddy covariance data of energy fluxes during and after the flooding cycle. For this area, the onset of the dry season coincides with the end of flooding and the return of the river water to its channel. The purpose of this article is to provide the first analysis of the variations in ET rates in the Bananal Island floodplain due to the seasonal fluctuations in the climatic variables (net surface radiation, air temperature, wind speed, air humidity and vapor pressure deficit) and hydrological conditions (height of flooding and soil moisture storage). The data encompasses 3 years worth of field data, 2004, 2005 and 2006.

\section{Description of Site, Measurements and Methods}

\subsection{Site Description}

[6] The experimental site is located in a floodplain area in the reserve of Cantão State Park (CSP), about 260km west of Palmas, Tocantins state, Brazil (Figures 1a-1b). The reserve covers 89,000 ha of a preserved area between two dominant biomes, the Amazon forest in the west and the Cerrado (Brazilian savanna) in the east, bounded in southwest by the Bananal Island region along both the Araguaia and the Javaés rivers (Figure 1b). The Bananal Island is $\sim 80 \times 260 \mathrm{~km}$ wide and it is the largest river island of the world, mostly covered with savanna and grassland that floods seasonally. The measurements were recorded using a micrometeorological tower about $2 \mathrm{~km}$ east of Javaezinho river, a tributary of the Javaés river $\left(9^{\circ} 49^{\prime} 16.1^{\prime \prime} \mathrm{S}\right.$; $\left.50^{\circ} 08^{\prime} 55.3^{\prime \prime} \mathrm{W}\right)$ (Figure 1b). The climate is hot and seasonally humid, with mean precipitation of $1755 \mathrm{~mm} \mathrm{yr}^{-1}$ and mean monthly temperature of $25.1^{\circ} \mathrm{C}$ in January to $26.4^{\circ} \mathrm{C}$ in September (Figure 1c). The dry season is between May and September 
Table 1. Calculated Coefficients of the Equation $\theta(\tau)=a\left[1+(d-1) \cdot e^{-k(\tau-\tau \mathrm{c})}\right] 1 /(1-d)$, Where $\theta$ is the Volumetric Soil Moisture in $\mathrm{m}^{3} \mathrm{~m}^{-3} ; \tau$ is the Reflectometer Output in $\mathrm{ms}$; and $\tau c, a, d$ and $k$ are Coefficients $\left(r^{2}>0.98\right)$, for Two Depths at an Arenosol Beneath a Woodland Savanna [da Rocha et al., 2002]

\begin{tabular}{|c|c|c|c|c|c|c|c|c|c|}
\hline \multirow[b]{2}{*}{ Depth $(\mathrm{cm})$} & \multicolumn{4}{|c|}{$\begin{array}{l}\text { Minimum and Maximum Values for } \tau(\mathrm{ms}) \\
\text { and } \theta(\tau)\left(\mathrm{m}^{3} \mathrm{~m}^{-3}\right)\end{array}$} & \multicolumn{4}{|c|}{ Calculated Parameters } & \multirow{2}{*}{$\frac{\text { Regression Coefficient }}{\mathrm{R}^{2}}$} \\
\hline & $\tau_{\min }$ & $\theta\left(\tau_{\min }\right)$ & $\tau_{\max }$ & $\theta\left(\tau_{\max }\right)$ & $a$ & $\tau c$ & $d$ & $k$ & \\
\hline 5 & 0.715 & 0.012 & 1.275 & 0.445 & 0.64535 & 0.85931 & 0.33234 & 2.54572 & 0.9987 \\
\hline 55 & 0.714 & 0.01 & 1.189 & 0.413 & 1.14829 & 0.85702 & 0.16037 & 1.10645 & 0.9997 \\
\hline
\end{tabular}

(mean relative humidity of $40 \%$ ), and the wet season (mean relative humidity of $90 \%$ ) with $\sim 90 \%$ of the annual rainfall. Most of the CSP is affected by annual floods that raise the water level from 1 to $5 \mathrm{~m}$ above the surface, in periods of up to 5 months from January to June. As describe in SEPLAN (Management Plan of the Cantão State Park, in Portuguese, 2004), the decrease of the water table height after the flooding help to form about 800 natural lakes across the reserve. Deeper lakes become isolated during the late dry season (July to September) while the shallower ones dry out. Four main ecosystems are found at CSP, namely, (1) the semideciduous forest (known as mata de torrão) that covers 47,000 ha over the highest patches that flood only during wet periods; (2) the seasonally flooding forest (known as mata de igapó) that cover 24,000 ha, surrounding the water channels and lakes, and is partially submersed for 5 to 8 months; (3) the swamps (known as varjão), natural grassland with high level of nutrients deposited mainly during the floods, that cover about 724 ha; and (4) the inner waters, a system covering 8148 ha composed by interconnected lakes and channels during the floods, that become blocked in several ways by sand banks during the dry season.

[7] The landscape surrounding the micrometeorological tower floods during the wet season. The ecosystem is composed of the semideciduous forests (in all azimuthal directions), a high woodland savanna with $18 \mathrm{~m}$ canopy height and sparse shrubs, and particularly the Cerrado, about $500 \mathrm{~m}$ in the east direction, a dense scrub with $5 \mathrm{~m}$ height trees and grass understory (Figure 1d). The varjão (natural grassland) is found in the lower lands. The soils are hydromorphic sandy soil (Gley humic). Although the experimental site is in a region classified as ecotone (Instituto Brasileiro de Geografia e Estatística-IBGE, Brazilian Institute of Geography and Statistic), the landscape surrounding the tower is not strictly ecotonal [Neiff, 2003], as the different ecosystems touch each other along well defined boundaries.

\subsection{Measurements}

[8] The measurements were made from October 2003 to December 2006 with a set of atmospheric sensors placed at the top of a $42 \mathrm{~m}$ iron scaffolding tower, including $30 \mathrm{~min}$ averages of temperature and humidity (HMP45C Vaisalla, Campbell Scientific Inc (CSI), Logan, Utah), wind speed (Met One 014, Grants Pass, Oregon, USA), rainfall (Hydrological Services), soil heat flux (REBS HFT3.1, Seattle, Washington, USA) and net radiation (NR Lite Net radiometer, CSI), using a datalogger (CR-10X, CSI). A profile of 10 thermocouples (CSI) installed on the tower measured the air and water layer (when flooded) temperature. For the measurements of energy and water fluxes, an eddy covariance system composed of a three-axis sonic anemometer (CSAT3, CSI) and an open-path infrared gas analyzer (Li-Cor 7500, Li-Cor, Lincoln, Nebraska, USA) connected to a second datalogger (CR-5000, CSI) measured the wind speed velocity components, virtual air temperature and concentrations of water and carbon dioxide at a rate of $10 \mathrm{~Hz}$.

[9] Soil moisture measurements were made using frequency domain reflectometers (CS615G, CSI) near the micrometeorological tower, placed horizontally in a shaft wall at the depths of $0.1,0.2,0.5,1.0,1.5$ and $2.0 \mathrm{~m}$, from October 2003 to October 2005. In December 2005 the pit was rebuilt and extended to $3 \mathrm{~m}$ depth, with sensors placed at $0.2,0.4,0.8,1.5,2.2$ and $2.9 \mathrm{~m}$. The volumetric soil moisture was estimated using a polynomial calibration of sandy soils under a Brazilian savanna area, that provided calculations with a sigmoid function that constrained the asymptotic lower (dry soil) and upper (saturated) soil moisture limits (Table 1). Soil porosity was estimated as the maximum soil moisture at each depth observed in the flood period (soil saturation degree of $100 \%$ ). The values obtained were $0.78,0.65,0.60,0.58,0.58$, and $0.62 \mathrm{~m}^{3} \mathrm{~m}^{-3}$, for the depths of $0.1,0.2,0.5,1.0,1.5$ and $2.0 \mathrm{~m}$, respectively.

[10] The flood height was manually recorded by observations of hydrometric rulers at the tower every 3 weeks. Groundwater level was measured in five wells using simple piezometers, made with plastic PVC tubes $(5 \mathrm{~cm}$ diameter, up to $5.0 \mathrm{~m}$ long) along a $1.1 \mathrm{~km}$ transect from the micrometeorological tower eastward (Figure 1d). The monitoring wells P2 (under semideciduous forest), P1 and P4 (both under the transition from semideciduous forest to Cerrado) were installed, respectively, at $1.69 \mathrm{~m}, 0.99 \mathrm{~m}$ and $0.42 \mathrm{~m}$ above the tower base height, whereas P3 and P5 (both under the savanna vegetation) were, respectively, at $0.11 \mathrm{~m}$ and $0.35 \mathrm{~m}$ below the tower base height (Figures 1d).

\subsection{Computation of Fluxes, Energy Balance and Footprint}

[11] Atmospheric fluxes of sensible heat, $H$, and water vapor, $\lambda E$, were calculated as $30 \mathrm{~min}$ averages, based on the eddy covariance technique, expressed as:

$$
\begin{gathered}
H=\rho_{a} C_{p} \overline{w^{\prime} T^{\prime}} \\
\lambda E=\lambda\left(1+\frac{\rho_{w}}{\rho_{a}} \frac{M_{a}}{M_{w}}\right)\left(\overline{w^{\prime} \rho_{w}^{\prime}}+\frac{\overline{w^{\prime} T^{\prime}}}{T}\right)
\end{gathered}
$$


where $\overline{w^{\prime} T^{\prime}}$ and $\overline{w^{\prime} \rho_{w}^{\prime}}$ are the 30 min covariances between the vertical wind speed, $w$, and temperature, $T$, and water vapor density, $\rho_{w}$, respectively, $\rho_{a}$ is the mean air density, $C_{p}$ is the specific heat of air, $\lambda$ is the latent heat of evaporation, $M_{a}$ and $M_{w}$ are the molecular weights of dry air and water vapor, respectively. Note that equation (1b) incorporates the correction introduced by Webb et al. [1980], which accounts for air density fluctuations that could be erroneously attributed to fluctuations in scalar concentrations. Additionally, standard frequency-response corrections (described in the study by Moore and Fisch [1986] and Moncrieff et al. [1997]) were applied to the fluxes.

[12] For a quality check of the measured fluxes, we analyzed the closure of the energy balance, by comparing the sum of estimated atmospheric turbulent fluxes with the available energy as

$$
(\lambda \mathrm{E}+\mathrm{H}) \approx(\mathrm{Rn}-\mathrm{G}-\mathrm{S})
$$

where $\mathrm{Rn}$ is the net radiation, $G$ is the soil heat flux, $S$ is the rate of change of heat storage in biomass and environment estimated as

$$
\mathrm{S}=\mathrm{S}_{\mathrm{air}}+\mathrm{S}_{\mathrm{bio}}+\mathrm{S}_{w l}
$$

where $S_{\text {air }}$ is the heat storage rate in the air resulting from changes in air temperature and specific humidity, $\mathrm{S}_{\mathrm{bio}}$ is the heat storage rate in the biomass, that were both estimated following Moore and Fisch [1986], as

$$
\begin{gathered}
\mathrm{S}_{\mathrm{air}}=16.7 \delta \mathrm{T}+28.9 \delta \mathrm{q} \\
\mathrm{S}_{\mathrm{bio}}=12.6 \delta \mathrm{T}^{*} .
\end{gathered}
$$

where $\delta \mathrm{T}$ and $\delta \mathrm{q}$ are hourly changes of air temperature and specific humidity, $\delta \mathrm{T}^{*}$ is the one hour in advance of the biomass heat storage estimates; $\mathrm{S}_{\mathrm{wl}}$ is the energy storage in the water layer, that was calculated as

$$
S_{w l}=\frac{\rho_{H 2 O}{ }^{c} H 2 O}{\Delta t} \Delta T_{w l} h
$$

where $\left(\Delta T_{w l}\right)$ are the changes in water temperature measured by thermocouples, $\rho_{\mathrm{H}_{2}} \mathrm{O}$ and $c_{\mathrm{H}_{2}} \mathrm{O}$ are the density and specific heat of water, $h$ is the height of the water layer and $\Delta \mathrm{t}$ is the time interval.

[13] As discussed by Moore and Fisch [1986], the parameterization of $\mathrm{S}_{\text {bio }}$ using equation (4b) can, however, produce large random errors with fast changes in air temperature and following the recommendation given in their article, we limit the estimates of $\mathrm{S}_{\mathrm{bio}}$ within $\pm 30 \mathrm{Wm}^{-2}$. The term $\mathrm{S}_{\mathrm{wl}}$ was included in (2) only during the periods where the area near the tower was flooded (that is, $h$ is not equal to zero).

[14] To estimate the footprint of the eddy flux we used the parameterization of Hsieh et al. [2000] according to different wind sectors and values of Obukhov length $(L)$. The authors combined the results of a stochastic dispersion model with dimensional analysis to parameterize the footprint. The footprint function $f$ relates the measured flux,
$F\left(x, y, z_{m}\right)$ to the spatial distribution of upwind surface flux $S_{0}(x, y)$ (also termed source strength) by

$$
F\left(x, y, z_{m}\right)=\int_{-\infty}^{\infty} \int_{-\infty}^{x} S_{0}\left(x^{\prime}, y^{\prime}\right) f\left(x-x^{\prime}, y-y^{\prime}, z_{m}\right) d x^{\prime} d y^{\prime},
$$

where $x$ is the distance upwind, $y$ is the crosswind position and $z_{m}$ is the measurement height. Hsieh et al. [2000] found that $x /|L|$ ( $x$ here can be seen as the fetch requirement downwind, to achieve a desired normalized flux, $F / S_{0}$ ), can be expressed as

$$
\frac{x}{|L|}=\frac{-1}{k^{2} \ln \left(F / S_{0}\right)} D\left(z_{u} /|L|\right)^{P},
$$

where $k=0.4$ is the von Karman constant, $D$ and $P$ are similarity constants, and $z_{u}$ is a length scale defined as

$$
z_{u}=z_{m}\left(\ln \left(z_{m} / z_{0}\right)-1+z_{0} / z_{m}\right)
$$

where $z_{0}$ is the roughness length of the surface. The ratio $F / S_{0}$ represents the relative cumulative contribution to the flux at upwind distance $x$ : a $90 \%$ contribution is represented by $F / S_{0}=0.9$. Using the results of a Lagrangian model, Hsieh et al [2000] calculated the footprint for a range of $z_{m}, z_{0}$ and $L$ values, and found:

$$
\begin{aligned}
& D=0.28 ; P=0.59 \text { for unstable conditions, } \\
& D=0.97 ; P=1 \text { for near neutral conditions, } \\
& D=2.44 ; P=1.33 \text { for stable conditions. }
\end{aligned}
$$

[15] The authors then formulate an expression for the footprint function along the upwind direction as

$$
f_{y}=\frac{1}{k^{2} x^{2}} D z_{u}^{P}|L|^{1-P} \exp \left(\frac{-1}{k^{2} x} D z_{u}^{P}|L|^{1-P}\right) .
$$

[16] After separating data records with unstable conditions for a selected period and for different wind sectors, we estimate the footprint at $10 \mathrm{~m}$ intervals using equation (8). Finally, to generate a composite map of the footprint of the eddy covariance system, we add up all estimates of $f_{y}$ obtained for each wind sector class.

\section{Results and Discussion}

\subsection{Energy Balance Closure and Flux Footprint}

[17] The energy budget closure was computed for the flood and post-flood period for the 3 years analyzed using a linear regression of the sum of $30 \mathrm{~min}$ averages of turbulent fluxes $(H+\lambda E)$ against the available energy (calculated as the right hand side of equation (2)). The slope of the regressions for different periods of flood and dry seasons is presented in Table 2. With the exception of the dry season in 2005, the turbulent fluxes underestimated the available energy by $\approx 17$ to $25 \%$ during periods of flood, and by $\approx 22 \%$ in the post-flood (dry season) cases. 
Table 2. Calculated Coefficients in the Equation $\lambda E+H=a(\mathrm{Rn}$ $-G-S)+b$ for the Energy Balance Closure

\begin{tabular}{lcc}
\hline \multicolumn{1}{c}{ Period } & $a$ & $b$ \\
\hline 2004 Flood & 0.82 & 26.8 \\
2004 Post flood & 0.80 & 10.9 \\
2005 Flood & 0.75 & 25.9 \\
2005 Post flood & 0.65 & 10.3 \\
2006 Flood & 0.80 & 21.9 \\
2006 Post flood & 0.83 & 28.1 \\
\hline
\end{tabular}

[18] During the flooding periods the data looked more scattered than those on the dry periods. One possible explanation is that during flood uncertainties may be higher due to the estimation of energy storage rates in the water layer and possible mismatch of the footprints of the net radiation sensors and the measured turbulent fluxes. The flood period is where the footprint of the net radiometer (over a closed tall savanna) may differ most from the footprint of the turbulent fluxes, which is composed of large flooded areas. Moreover, the free water surfaces increases evaporation also during nighttime and particularly in windy conditions, which might have increased the scattering of data at low-radiation conditions and decrease the quality of the linear correlation. Nevertheless, similar failure to close the energy budget was observed in most of the forest sites elsewhere, where generally values between $1 \%$ and $47 \%$ were observed [Wilson et al., 2002].

[19] During the 2005 post-flood period, the raw data of latent heat flux was systematically lower than in the same period of other years. It was associated with the low closure of the energy balance and possibly with a poor calibration of the open-path gas analyzer. In this period, the latent heat flux was recalculated assuming the simple hypothesis that $\lambda E=a(\mathrm{Rn}-S-G)+b-H$. The coefficients $a=0.80$ and $b=10.9 \mathrm{Wm}^{-2}$ were estimated from the closure of the energy balance during the 2004 post-flood period (Table 2). This procedure increased the latent heat flux by only about $15 \%$, which in turn is about $20 \%$ less than the estimative of $\lambda E$ as the residue of the available energy [von Randow et al., 2004].

[20] Figure 2 shows a map of the footprint contributions of the eddy covariance and wind direction distribution

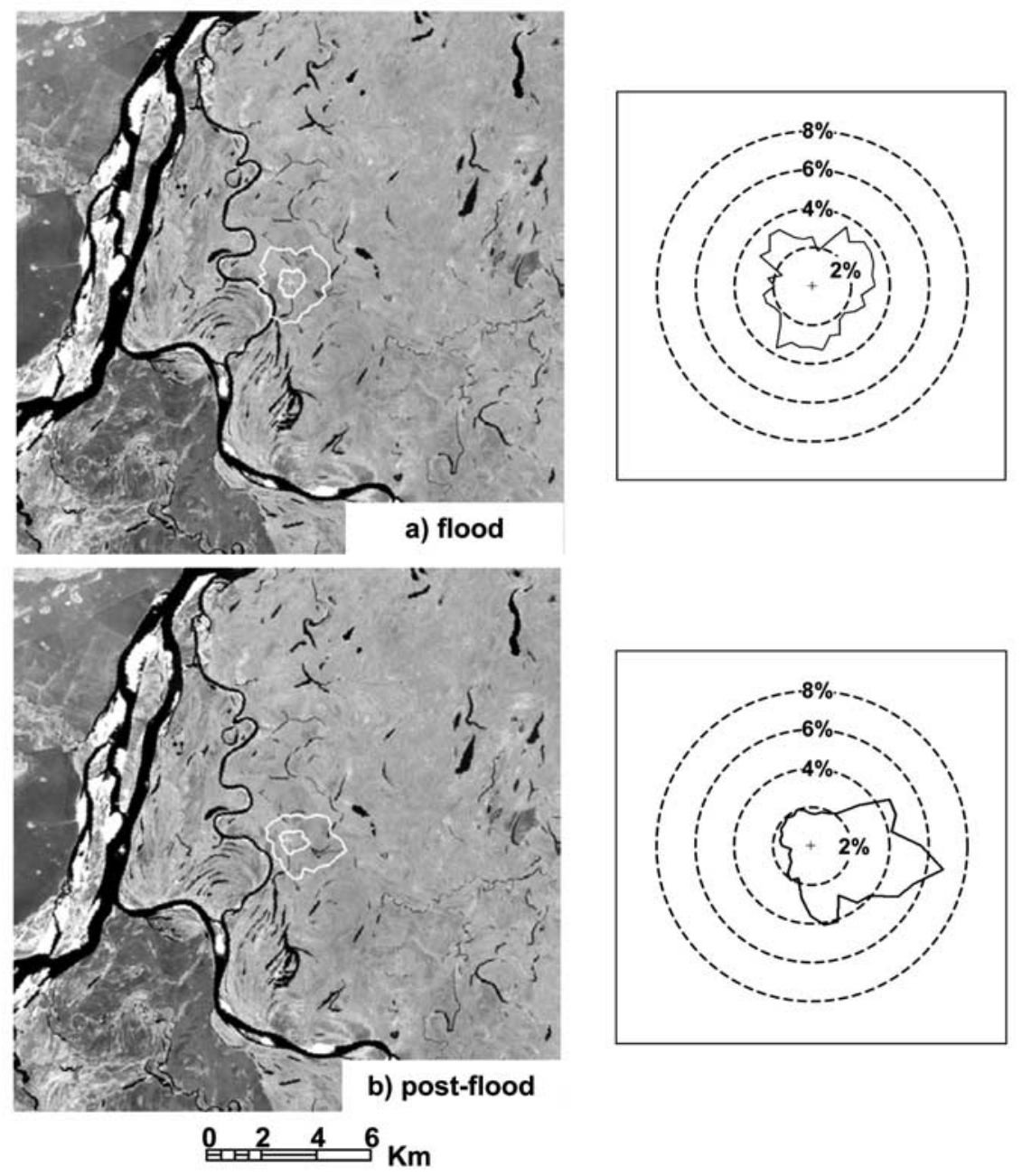

Figure 2. (left) Estimated footprint and (right) wind direction distribution in unstable atmospheric conditions for the (a) flooding period (February to June 2004) and (b) post-flooding period (July to September 2004). The lines in the footprint figures are accumulated probability distributions of $75 \%$ and $90 \%$, respectively, from the sensor position. 


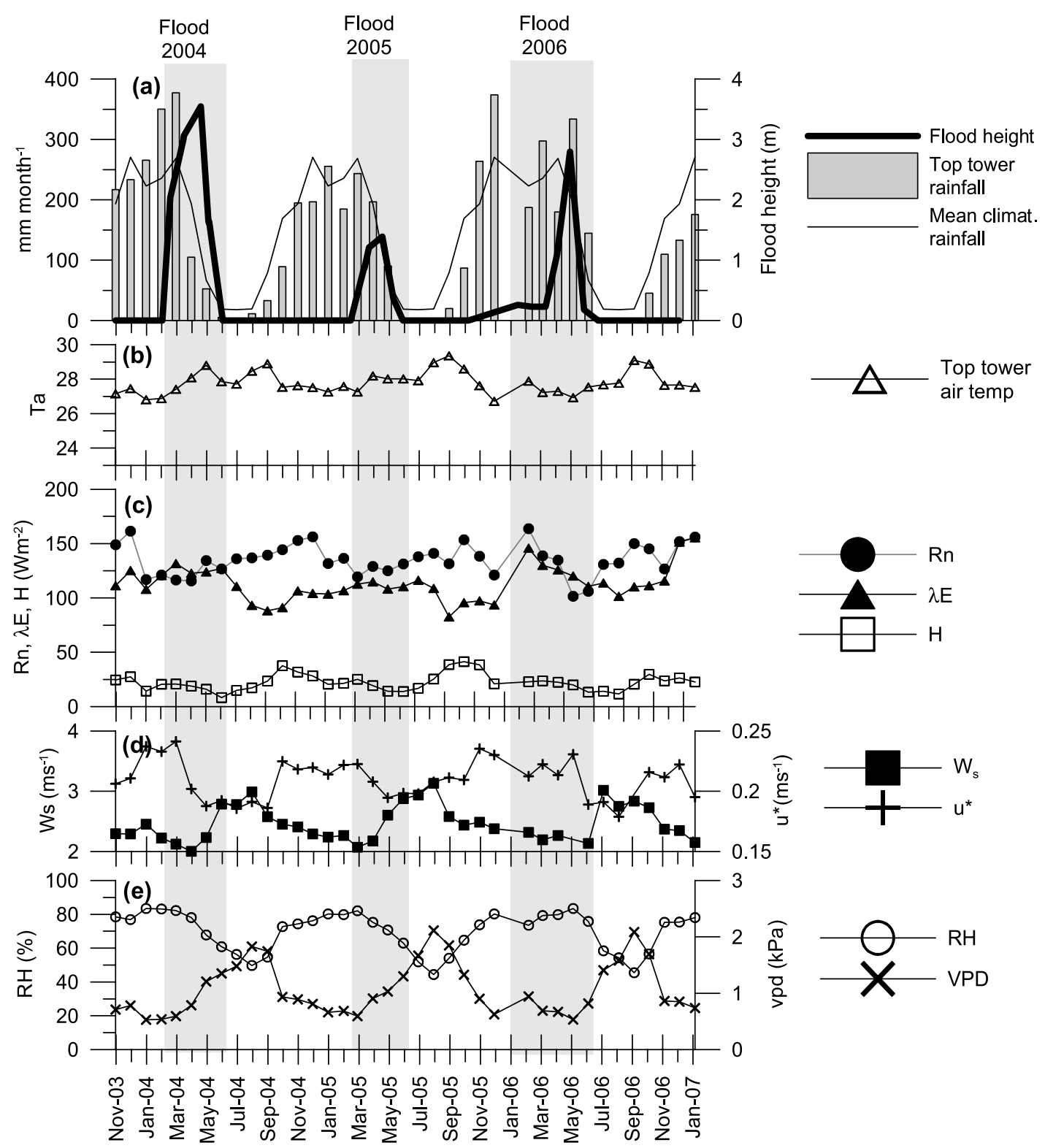

Figure 3. Monthly mean variables observed at the experimental site during the period November 2003 to December 2006. (a) Top tower precipitation (in $\mathrm{mm} \mathrm{month}^{-1}$, grey bar), climatological precipitation observed in Conceição do Araguaia (period of 1975 to 1998, in mm month ${ }^{-1}$, thin solid line), and flood height measured at the tower base (heavy solid line, in meter). (b) Top tower air temperature (in ${ }^{\circ} \mathrm{C}$, solid line with open triangles). (c) Net radiation (in $\mathrm{W} \mathrm{m}^{-2}$, solid line with filled circles), latent heat flux (in $\mathrm{W}$ $\mathrm{m}^{-2}$, solid line with filled triangles) and sensible heat flux (in $\mathrm{W} \mathrm{m}^{-2}$, solid line with open squares). (d) Horizontal wind speed (in $\mathrm{m} \mathrm{s}^{-1}$, solid line with filled squares) and friction speed (in m s${ }^{-1}$, solid line with crosses). (e) Air relative humidity (in \%, solid line with open circles) and water vapor pressure deficit (in $\mathrm{kPa}$, solid line with letter $\mathrm{X}$ ).

observed during both flood and post-flood period of 2004 . During 2005 and 2006, observations resemble these results (not shown). The calculated footprint showed slightly different wind direction dependence during the flood and post-flood period (Figures 2a and 2b). The wind direction pattern had contributions from nearly all directions during the flood (Figure 2a). Conversely, in the dry season, the prevailing wind direction was in the east-southeast sector (Figure 2b), which extended the footprint along the eastern sector of the tower. In both seasons, up to $90 \%$ of the footprint contribution came from around $2 \mathrm{~km}$ from the tower, covering the succession of landscapes described in Figure 1.

[21] From the observation that the energy balance closure was reasonably good (comparable to most forest flux towers worldwide) and the estimated footprints can be considered representative of the flood and non-flood conditions, we conclude that our flux measurements can be reliably used for the analyses presented in the following sections. 


\subsection{Climate and Flooding}

[22] The annual precipitation was 1692, 1471 and $1914 \mathrm{~mm}$ for the hydrological years, defined here as starting in October of the preceding year and ending in September, of 2004, 2005, and 2006, respectively (Table 2). The climatological rainfall observed at the Conceição do Araguaia rain gauge station (Figure 1d and Figure 3a) was $1755 \mathrm{~mm}$. Though the floods follow a similar pattern in the three years of observation, generally peaking in April (therefore in the end of the wet season), there was a clear interannual variability on the pattern of the wet season. The hydrological year 2004/2005 was the driest year, while the $2005 / 2006$ was the wettest one. In addition, the period of January 2006 was anomalously dry (Figure 3a). These features corroborate the patterns of the floods, which had the lowest height in 2005 (lower than $2 \mathrm{~m}$ ) and lasted longer in 2006 (Figure 3a). In fact, a widespread intense drought occurred in Amazonia during 2005, mostly over the western and southwestern sectors [Saleska et al., 2007; Marengo et al., 2008]. It may have also affected the climate over the region of the experimental site.

[23] In general, the seasonality of air temperature was well correlated with the net radiation. Monthly mean net radiation varied between 110 and $160 \mathrm{Wm}^{-2}$ (Figure 3c). The minimum net radiation occurred during the late wet season and was mostly controlled by the increasing cloud cover, while the maximum was in the early wet season, concurrent with increasing solar radiation. The air temperature varied between 25 to $28^{\circ} \mathrm{C}$ and peaked at the end of the dry season, between September and October (Figure 3b), influenced by the increasing net radiation and the large-scale subsidence. It also had a secondary maximum in May, affected by the onset of dry season. The minimum temperature was in July, in between the two maxima, controlled by the reduced solar radiation in winter solstice [ $d a$ Rocha et al., 2009]. During the flooding period, the mean monthly temperature was $\approx 26.1^{\circ} \mathrm{C}$ for the 3 years analyzed. However, in the post-flood period (July to September), the air temperature was of $26.4^{\circ} \mathrm{C}$ in 2004 and showed an increase of $\approx 1^{\circ} \mathrm{C}$ in the same period of 2005 and 2006, reaching the values of $27.4^{\circ} \mathrm{C}$ and $27.2^{\circ} \mathrm{C}$, respectively.

\subsection{Seasonality and Control of the Energy Fluxes}

[24] The seasonality of the sensible heat flux $(H)$ showed decreasing values during the wet season and increased slowly from the middle to the late dry season (Figure 3c). The maximum monthly average $H$ was around $40 \mathrm{Wm}^{-2}$, generally in October, while the minimum was around $10 \mathrm{Wm}^{-2}$. The increasing $H$ during the dry season is partly controlled by the increasing net radiation and partly by the reduction of rainfall and soil moisture. The monthly average soil heat flux was generally low and around -1 to $1 \mathrm{Wm}^{-2}$ (not shown). During the flood period the hourly measurements of the flux plates showed only small oscillation near zero.

[25] A progressive decrease of the latent heat flux $(\lambda E)$ occurred along the dry season. In general, $\lambda E$ was higher in the wet season and lower in the dry season (Figure $3 \mathrm{c}$ ). The maxima $\lambda E$ varied between 100 and $150 \mathrm{~W} \mathrm{~m}^{-2}$, and the minima were between 75 and $115 \mathrm{Wm}^{-2}$ for the entire period of measurements. Therefore the monthly mean Bowen ratio was higher in the late dry season, between September and October. As well, the mean monthly $H$ never exceeded the mean $\lambda E$, being the Bowen ratio less than 1.The $\mathrm{Rn}$ values during the flooding period $\left(\approx 120 \mathrm{Wm}^{-2}\right)$ were slightly lower than the values during the post-flooding period $\left(\approx 135 \mathrm{Wm}^{-2}\right)$. This pattern was attributed to the fact that the effect of cloudiness in the wet season was similar to the reduction of solar radiation in the winter, as discussed by da Rocha et al. [2009].

[26] Figure 3a illustrates that there was a negative correlation between $\lambda E$ and the net radiation, which can be observed by selecting two different periods of time: the first, from June (the end of the flooding) to September (late dry season), where net radiation increases while $\lambda E$ decreases; and the second, from October (early wet season) to May (late wet season), where just the opposite was observed, that is, $\lambda E$ increased while net radiation decreased.

[27] Other atmospheric variables which can control the ET also showed seasonality. The mean monthly wind speed generally decreased in the wet season $\left(\approx 2 \mathrm{~ms}^{-1}\right)$ and increased in the dry season $\left(\approx 3 \mathrm{~ms}^{-1}\right)$ (Figure $3 \mathrm{~d}$ ). This is in accordance with the climatology of surface atmospheric circulation in continental areas of South America. In additional, the average monthly water vapor pressure deficit (and air relative humidity) (Figure 3e) was lower (and higher) (0.8 $\mathrm{kPa}$ and $72 \%$, respectively) during the wet season, and higher (and lower) during the dry season $(1.7 \mathrm{kPa}$ and $54 \%$, respectively). The friction velocity $\left(\mathrm{u}^{*}\right)$ varied between 0.15 and $0.25 \mathrm{~m} \mathrm{~s}^{-1}$ year round (Figure $3 \mathrm{~d}$ ). Similarly to the net radiation, wind speed and air humidity did not help to explain the wet season $\lambda E$ increase in the flooding area. Other factors may prevail in influencing the seasonality of $\lambda E$ named, the reduction of the free water surface and the soil moisture depletion, as discussed later.

[28] On the interannual variability, the average ET during the flood period (February to June) of 2005 was lower $\left(3.9 \mathrm{~mm} \mathrm{day}^{-1}\right)$ than the values of 4.3 and $4.4 \mathrm{~mm} \mathrm{day}^{-1}$ obtained in the same period of 2004 and 2006, respectively (Table 3). Except for a small increase in the wind speed, the other atmospheric variables $\left(\mathrm{Rn}, \mathrm{Rh}, \mathrm{T}_{\mathrm{a}}\right.$ and VPD) did not show expressive variations between the analyzed years. On the other hand, the accumulated precipitation $(616 \mathrm{~mm})$ and the height of flooding $(1.4 \mathrm{~m})$ were much lower in 2005 than the values observed in the same period of the other years $(847 \mathrm{~mm}$ and $3.6 \mathrm{~m}$ in 2004 and $1108 \mathrm{~mm}$ and $2.8 \mathrm{~m}$ in 2006).

[29] On the basis of these findings, it can be seem that the hydrological pulse partly explains the lower ET values obtained during 2005 flooding period. The lower the flooding height and the shorter the flooding length, the extension of flooded area is smaller and, consequently, the free water surface that contributes to potential evaporation in the flooding period is reduced. These findings support the previous observation that, in the floodable area, the water availability (as free surface water) exerts larger influence over the ET rates than the net surface radiation.

\subsection{Soil Moisture and Groundwater}

[30] Temporal changes of groundwater level at the five wells and the Javaezinho river are shown in Figure 4a. The wells generally rose from the early rainy season, in October, until the onset of the flood, in January. The wells located at the lower levels (P3 and P5) rose in advance of those located at higher levels (P1, P2 and P4, respectively). The 
Table 3. Total Accumulated Rainfall, Evapotranspiration and Flooding Characteristics for the 2003-2006 Period

\begin{tabular}{|c|c|c|c|c|c|c|c|}
\hline \multirow[b]{3}{*}{ Period } & \multicolumn{2}{|c|}{ Hydrological Year (October-September) } & \multicolumn{5}{|c|}{ Flooding Period } \\
\hline & \multirow[b]{2}{*}{ Accumulated Rainfall ${ }^{\mathrm{a}}(\mathrm{mm})$} & \multirow[b]{2}{*}{ Accumulated $\mathrm{ET}^{\mathrm{a}}(\mathrm{mm})$} & \multicolumn{3}{|c|}{ Length } & \multirow[b]{2}{*}{ Height $(\mathrm{m})$} & \multirow[b]{2}{*}{ Average ET $\left(\mathrm{mm} \mathrm{day}^{-1}\right)$} \\
\hline & & & Begin & End & Days & & \\
\hline $2003 / 2004$ & 1692 & 1361 & 03 February 2004 & 07 June 2004 & 125 & 3.6 & 4.3 \\
\hline $2004 / 2005$ & 1471 & 1318 & 17 February 2005 & 02 June 2005 & 105 & 1.4 & 3.9 \\
\hline $2005 / 2006$ & 1914 & 1317 & 05 January 2006 & 05 June 2006 & 151 & 2.8 & 4.4 \\
\hline
\end{tabular}

${ }^{\mathrm{a}}$ In 2004, the measurements at Bananal tower began on 24 October 2004.

deepest level was between $3.7 \mathrm{~m}$ to $4.5 \mathrm{~m}$ below the surface for most of the wells. Except for P3 (where the deepest level was only $2.5 \mathrm{~m}$ ), the minimum groundwater level matched the minimum water level of Javaezinho river in the late dry season. These results showed that, as expected, there is a strong relation between groundwater and river water levels. The deeper levels did not show noticeable changes between the analyzed years.

[31] The volumetric soil moisture daily means at several depths are shown in Figure 4b. The shallowest depth $(0.1 \mathrm{~m})$ showed the most pronounced variation year round, from 0.2 to $0.8 \mathrm{~m}^{3} \mathrm{~m}^{-3}$. Measurements at other depths varied between approximately 0.2 (in the dry season) and $0.6 \mathrm{~m}^{3} \mathrm{~m}^{-3}$ (in the flood). The soil is generally very porous given its prevailing sandy texture, although the vertical soil profile is not entirely homogeneous. The highest porosity of shallow layers $(0.1$ and $0.2 \mathrm{~m}$ ) (see 2.2$)$ is probably affected by roots and organic matter at various decomposition stages that increase macropores.

[32] The drainage was likely very strong as the shallower layers were not significantly affected by the first events of rainfall between October and December 2004 (Figure 5). In December 2004, the middle and deep soil layers saturated quickly, in advance of the shallow layers. The wetting of the soil column progressed from the bottom-up as a result of the inundation. As the flooding ceased in June 2004, there was a slow top-down drying of the soil column. It took about 4 months until the $2 \mathrm{~m}$ depth dried out to approximately $60 \%$, and the shallow layers to about $20 \%$. Furthermore, in the post-flooding period of June 2005, the $2 \mathrm{~m}$ depth dried to about $70 \%$, which was drier compared to 2004 . Since the groundwater level was around $4 \mathrm{~m}$ deep near the moisture probes, it is likely that upward water movement from capillary forces helped to keep the $2 \mathrm{~m}$ soil column as wet as noticed that the early wet season.

[33] Figure 6 shows in detail the daily mean soil moisture profile in the dates of the maximum flooding height and in the late dry seasons. These profiles show the extreme soil moisture conditions year round and highlight that the soil was slightly drier in 2005 compared to 2004 .

[34] For the hydrological year (October-September) the accumulated precipitation was $1692,1471,1914 \mathrm{~mm}$ and the accumulated ET was 1361, 1318 and $1317 \mathrm{~mm}$ from October 2003 to September 2006. The soil moisture loss (SML) was, respectively, $609 \mathrm{~mm}, 687 \mathrm{~mm}$ and $560 \mathrm{~mm}$ for the 2004, 2005 and 2006 post-flooding periods (Figures 7a, $7 \mathrm{~b}$ and $7 \mathrm{c})$. The accumulated ET for the same periods was $413 \mathrm{~mm}, 433 \mathrm{~mm}$ and $443 \mathrm{~mm}$, respectively. The SML was

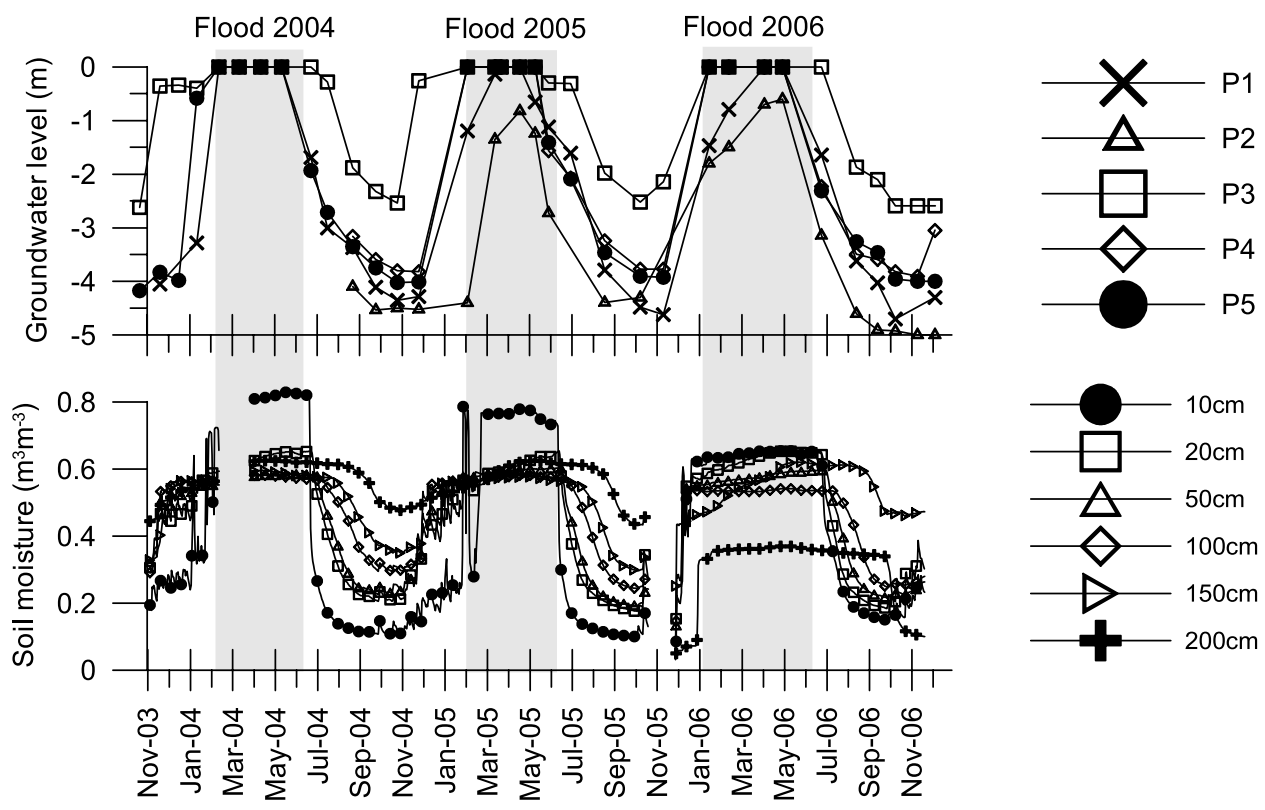

Figure 4. (a) Groundwater level (in meters) for five wells (P1 to P5, respectively, as shown in transect of Figure 1d). The reference level (equal to zero) is the ground surface each well, so groundwater level is negative. (b) Daily mean monthly volumetric soil moisture $\left(\mathrm{in}^{3} \mathrm{~m}^{-3}\right.$ ) for the following depths: 10, 20, $50,100,150$ and $200 \mathrm{~cm}$ (labeled as in the legend). Grey bar is the flood period. The measuring period was November 2003 to December 2006. 


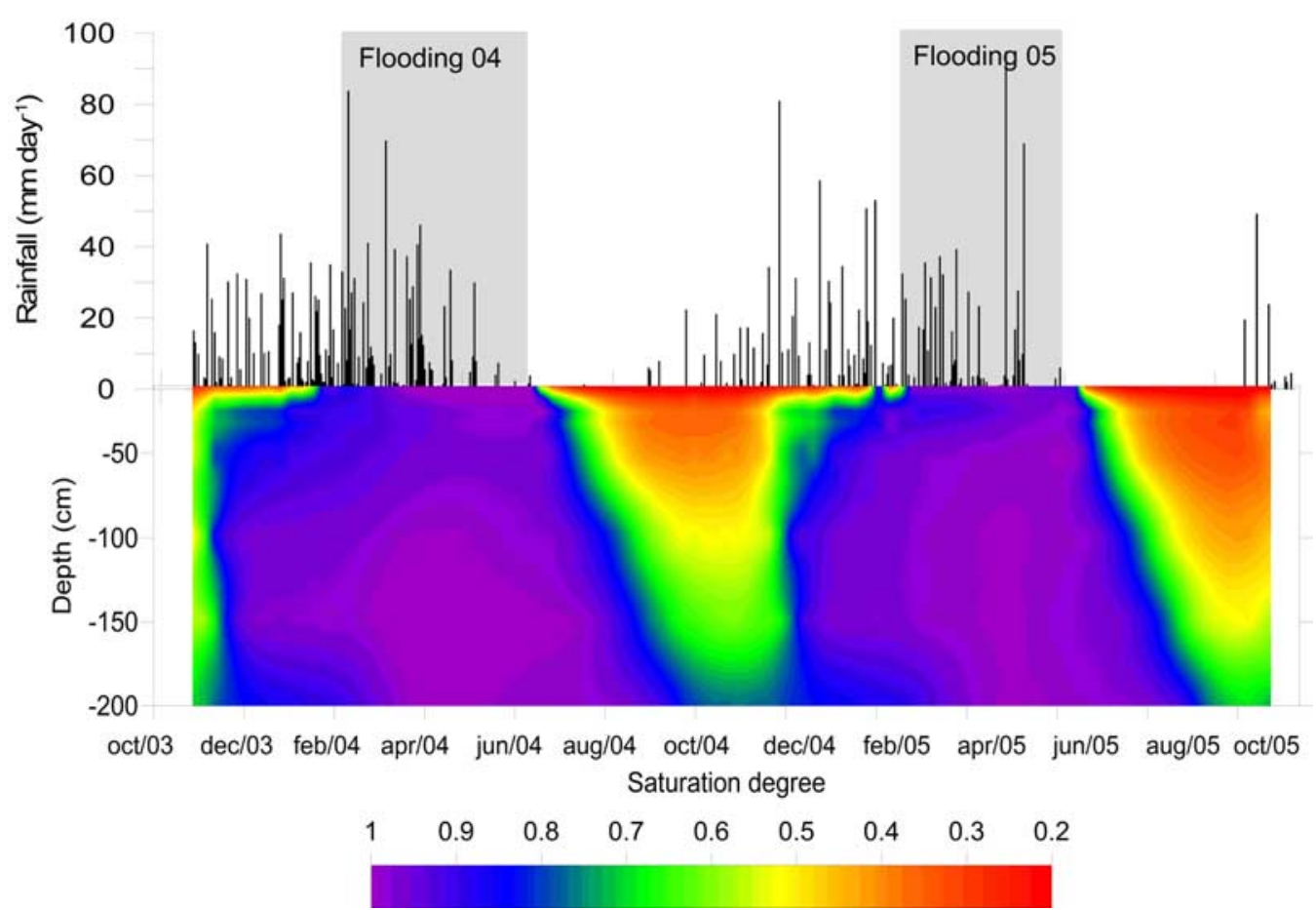

Figure 5. Mean daily precipitation $\left(\mathrm{mm} \mathrm{day}^{-1}\right)$ (top) and saturation degree $(\times 100 \%)$ (volumetric soil moisture upon porosity) (bottom) based on interpolation of values of Figure 5 between 0.1 and $2.0 \mathrm{~m}$ depth. The measuring period was November 2003 to December 2005.

greater than the accumulated ET minus precipitation $(413-46=367 \mathrm{~mm})$ in about $242 \mathrm{~mm}$, indicating a substantial drainage of about $2.1 \mathrm{~mm} \mathrm{day}^{-1}$ in 2004. Similarly, drainage was of $2.3 \mathrm{~mm} \mathrm{day}^{-1}$ and $1.4 \mathrm{~mm} \mathrm{day}^{-1}$ for the 2005 and 2006 years, respectively. These results show that the water loss due to internal drainage is very important in this system.

[35] Figures 7a to 7c (upper part) shows that the ET substantially decreased as long as the dry season progressed, mainly for the 2004 and 2005 years. In fact, the average ET values for the first and last 10 days of the post-flooding period were calculated for the 2004 and 2005 years. The values obtained were, respectively, 4.7 and $3.1 \mathrm{~mm} \mathrm{day}^{-1}$ for 2004 and 3.7 and $2.3 \mathrm{~mm} \mathrm{day}^{-1}$ for 2005. For the wettest years (2004 and 2006), the rates of soil moisture loss in the 2.0-m-deep layer (in 2004) and 2.9-mdeep layer (in 2006) were greater than the ET daily rates for the post-flooding (dry) period (Figures $7 \mathrm{a}$ to $7 \mathrm{c}$, lower part). It can be concluded from these findings that the water stored in the $2.0 \mathrm{~m}$ for 2004 (and $2.9 \mathrm{~m}$ for 2006) seemed enough to supply the ET and drainage processes that took place during the entire dry period. However, in the driest year (2005), later in the dry season, the soil moisture stored in the 2.0-m-deep layer seemed to be not enough to supply the ET rates (Figure 7b). For this period, the system probably accessed water from the deeper soil layers to satisfy the atmospheric ET driving forces.

\section{Discussion}

[36] For the three years analyzed, the post-flooding period ET (average $3.7 \mathrm{~mm} \mathrm{day}^{-1}$ ) was lower than the flooding period ET (average $4.1 \mathrm{~mm}^{\mathrm{day}}{ }^{-1}$ ). Rn had an opposite behavior, with greater values occurring in the post-flooding period (average $137.1 \mathrm{Wm}^{-2}$ ) than in the flooding period (average $125.4 \mathrm{Wm}^{-2}$ ). This pattern is not in agreement with the results obtained in Amazonia upland forests, where ET tended to be maintained or was even higher in the dry season and in phase with net radiation [Shuttleworth, 1988; Negrón-Juarez et al., 2007 and others]. The increasing ET in the wet season and particularly in the flooding period indicates that the free surface water plays a dominant role in the water exchange during the wet season, in the floodable area. When the wetlands are inundated, ET is mainly controlled by the atmospheric driving forces (potential ET rate).

[37] In the Amazon upland forests, the ET seems to be largely controlled by the net radiation while the dry period does not seems to cause water stress to the point of dropping

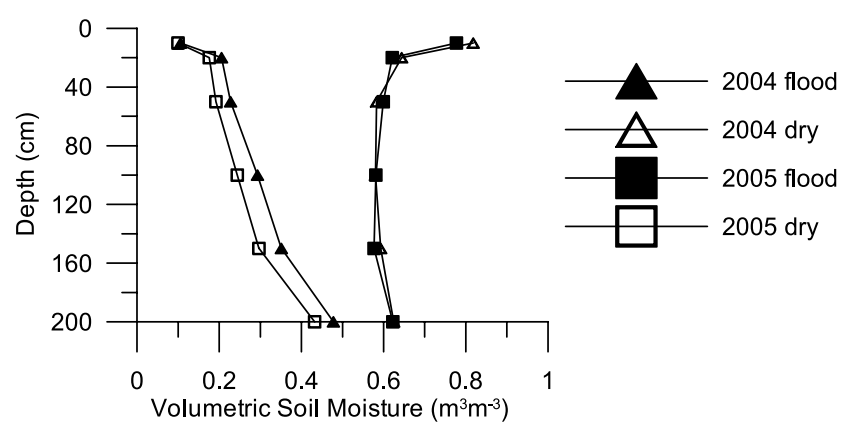

Figure 6. Vertical profile of measured daily mean volumetric soil moisture (in $\mathrm{m}^{3} \mathrm{~m}^{-3}$ ), selected in 20 April 2004 (filled triangles), 10 September 2004 (open triangles), 20 April 2005 (filled squares), 29 September 2005 (open squares). 
a) 2004
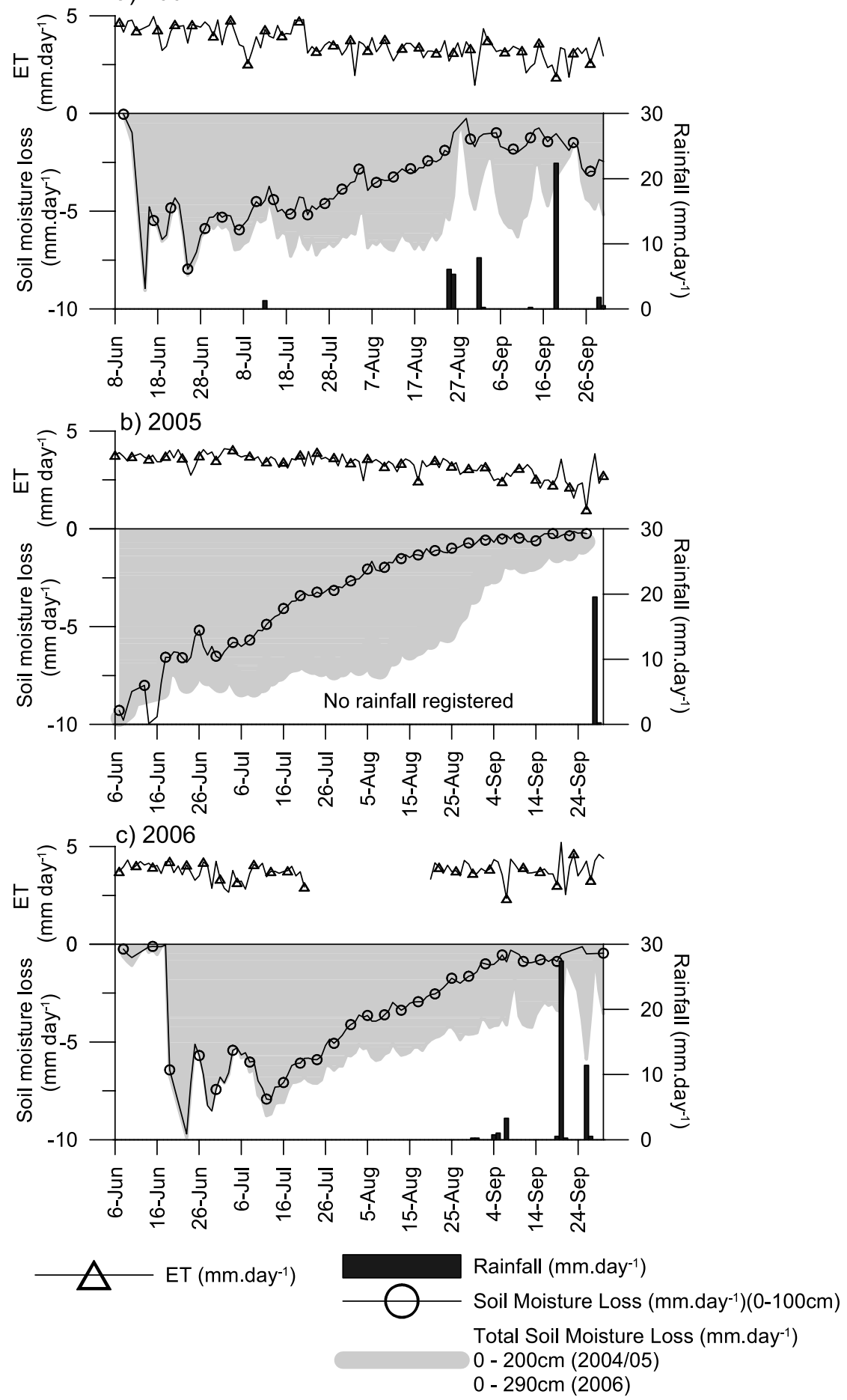

Figure 7. Rate of soil moisture loss for the first $1.0 \mathrm{~m}$ layer (line with open circles), rate of soil moisture loss for the 2-m-deep layer (2004 and 2005) and 2.9-m-deep layer (2006) (light gray area), evapotranspiration daily rates (open triangles) and daily mean rainfall (black column). Period: postflooding period (first week of June to end of September) in the years (a) 2004, (b) 2005 and (c) 2006.

the ET rates to values lower than wet season. Negrón-Juarez et al. [2007] observed that the dry season ET in South West Amazonia was supported by the soil moisture stored in the previous wet season. The same cannot be said about the transitional forests in Amazonia and savannas in the Brazilian central region, where the soil water stress significantly influences the ET rates, mainly during the dry season [ $d a$ Rocha et al., 2009].

[38] The ability of Amazon upland forests to maintain high ET rates even for long dry periods had been attributed to the sufficient soil moisture conditions and to an efficient and deep root system, able to extract water even from the 
deepest soil layers [Nepstad et al., 1994; Jipp et al., 1998]. Chauvel et al. [1992] found abundant roots at depths of 3 to 6 m. Nepstad and Serrão [1991] and Nepstad et al. [1994] found roots at $18 \mathrm{~m}$ deep and Nepstad [1989] concluded that the mature forest in Eastern Amazon (Paragominas, PA) reaches water at $6 \mathrm{~m}$ deep. In this work, we found that, for the wet to normal climatological years (2004 and 2006), the water stored in the $2.0 \mathrm{~m}(2.90 \mathrm{~m}$, for 2006$)$ soil profile layer was enough to maintain average ET rates around $3.7 \mathrm{~mm} \mathrm{day}^{-1}$ throughout the whole dry season. However, in the driest year, 2005, water had to be extracted from soil layers deeper than $2 \mathrm{~m}$, to maintain the ET rates at the end of the post-flooding period. For all the years analyzed, vegetation adaptative mechanisms like leaf senescence were observed in the later dry season. This must have limited the dry season ET.

[39] Because of the fact that deep seepage and root extraction were taking place simultaneously, a noticeable loss of water was observed in the floodable area after the flooding ceased. ET showed a substantial and consistent reduction along the dry season for the three years analyzed. Additionally, the floodable ecosystem presented only a tiny memory of the flooding period, progressively decreasing the ET rates during the dry period (Figures $7 \mathrm{a}$ and $7 \mathrm{~b}$ ). Such a pattern is characteristic of the savanna species, in which the dominant root system do not reach deep waters, but the aerial part of vegetation is adapted with mechanisms such as tree leaf senescence and dormancy of grasses.

\section{Conclusions}

[40] This article discusses the seasonal and interannual variability of ET and soil moisture in a seasonal floodplain area over savanna vegetation within the transition zone of the forest-savanna in Amazonia. The results showed that the ET in the flooding period (average $4.1 \mathrm{~mm} \mathrm{day}^{-1}$ ) was greater than the ET in the post-flooding period (average $3.7 \mathrm{~mm} \mathrm{day}^{-1}$ ), mainly influenced by the evaporation from the water layer. A decrease in the dry season ET occurred in spite of a simultaneous increase in the net radiation, air temperature and water vapor deficit. This pattern is not in agreement with the results obtained in terra firme Amazonian sites. At these sites, ET is driven by the energy surface inputs and, in the absence of soil water stress, the dry season ET is even greater than the wet season ET. On the other hand, the pattern observed at our site is similar to that found in transition areas in southeast Amazonia and savanna strictu senso areas in central Brazil, where the soil water stress limits the ET during the dry season. For the hydrological year (October-September) the accumulated precipitation was 1692, 1471, $1914 \mathrm{~mm}$ and the accumulated ET was 1361, 1318 and $1317 \mathrm{~mm}$ from October 2003 to September 2006.

[41] The vegetation over these floodplain forests in Amazonia can erroneously be thought as an ecosystem that has abundant water availability. Strong drainage within very permeable sandy soils is apparently the main process that helps to explain the transition of soil moisture between the seasons. The wet season ET is increased by the event of flooding and the free surface water evaporation. Dry season ET, although partly sustained by soil water stored in the previous flood, is progressively reduced until the onset of the following wet season.

[42] Acknowledgments. We thank those who contributed to the conception and maintenance of the experimental site in the Bananal Island region: Antonio Manzi, Carlos Nobre, Michael Keller, Divaldo Rezende, Stefano Merlin, Rita Ribeiro, Antonio Carlos Lola da Costa (tower building), Plácido Sousa Beserra and Márcio Antonio da Silveira (UFT) and Soraya Rodrigues da Silva (LBA). We also thank Carlos Nobre and LuZ Adriana Cuartas for some important discussions and Thiago Borma Chagas for the English revision. We thank the support of the following institutions and projects: Fapesp (02/09289-9) and CNPq (Instituto do Milênio, LBA, Ed. Universal-01, Ed. CT-Hidro 03).

\section{References}

Bruno, R. D., H. R. da Rocha, H. C. Freitas, and S. D. Miller (2006), Soil moisture in an eastern Amazonian tropical forest, Hydrol. Processes, 2 , 2477-2489.

Chauvel, A., A. R. T. Vital, Y. Lucas, T. Desjardins, W. K. Franklen, F. J. Luizão, L. A. Araguás, K. Rozanski, and A. P. Bedmar (1992), The Role of Roots Over the Forest Hydrological Cycle, (in Portuguese), pp. 298-302, VII Brasilian Congress on Meteorology, São Paulo, Brazil.

da Rocha, H. R., M. Goulden, S. Miller, M. Menton, L. Pinto, L. A. Freitas, and A. S. Figueira (2004), Seasonality of water and heat fluxes over a tropical forest in eastern Amazonia, Ecol. Appl., 14(4), S22-S32.

da Rocha, H. R., et al. (2009), Patterns of water and heat flux across a biome gradient from tropical forest to savanna in Brazil, J. Geophys. Res., doi:10.1029/2007JG000640, in press.

Goulden, M. L., S. D. Miller, H. R. da Rocha, M. C. Menton, H. C. de Freitas, A. M. E. S. Figueira, and C. A. D. de Sousa (2004), Diel and seasonal patterns of tropical forest $\mathrm{CO}_{2}$ exchange, Ecol. Appl., 14(suppl.), S42S54

Hess, L. L., J. M. Melack, E. M. L. M. Novo, C. F. C. Barbosa, and M. Gastil (2003), Dual-season mapping of wetland inundation and vegetation for the central Amazon basin, Remote Sens. Environ., 87, 404-428.

Hodnett, M. G., I. Vendrame, M. D. Oyama, O. A.de Marques Filho, and J. Tomasella (1997), Soil water storage and groundwater behaviour in a catenary sequence beneath forest in Central Amazônia, II: Floodplain water table behaviour and implications for streamflow generation, Hydrol. Earth Syst. Sci., 1, 279-290.

Hsieh, C.-I., G. Katul, and T. Chi (2000), An approximate analytical model for footprint estimation of scaler fluxes in thermally stratified atmospheric flows, Adv. Water Resour., 23, 765-772.

Jipp, P. H., D. C. Nepstad, D. K. Cassel, and C. R. de Carvalho (1998), Deep soil moisture storage and transpiration in forests and pastures of seasonally-dry Amazonia, Clim. Change, 39, 395-412.

Marengo, J., C. A. Nobre, J. Tomasella, M. D. Oyama, G. S. Oliveira, R. de Oliveira, H. Camargo, L. M. Alves, and I. F. Brown (2008), The drought of Amazonia in 2005, J. Clim., 21(3), 495-516.

Moncrieff, J. B., et al. (1997), A system to measure surface fluxes of momentum, sensible heat, water vapour and carbon dioxide, J. Hydrol., $189(1-4), 589-611$.

Moore, C. J., and G. Fisch (1986), Estimating heat storage in Amazonian tropical forest, Agric. For: Meteorol., 38, 147-169.

Negrón-Juarez, R. I. N., M. G. Hodnett, R. Fu, M. L. Goulden, and C. von Randow (2007), Control of dry season evapotranspiration over the Amazonian forest as inferred from observations at a Southern Amazon forest site, J. Clim., 20, 2827-2839.

Neiff, J. J. (2003), Planícies de inundação são ecótonos?, in Ecotonos nas interfaces dos ecossistemas aquáticos, cap. 2, Henry, R. (org), pp. $32-$ 47, RIMA Editora, São Carlos, Brazil.

Nepstad, D. C. (1989), Forest regrowth on abandoned pastures in eastern Amazonia: Limitations to tree seedling survival and growth, Ph.D. thesis, Yale Univ. Press, New Haven, Conn.

Nepstad, D. C., and D. A. S. Serrão (1991), Recuperation of a degraded Amazonian landscape: Forest recovery and agricultural restoration, Ambio, $20,248-255$

Nepstad, D. C., C. R. De Carvalho, E. A. Davidson, P. H. Jipp, P. A Lefebvre, G. H. Negreiros, E. D. Silva, T. A. Stone, S. E. Trumbore, and S. Vieira (1994), The role of deep roots in the hydrological and carbon cycles of Amazonian forests and pastures, Nature, 372, 666-669.

Oliveira, R. S., T. E. Dawson, S. O. Burges, and D. C. Nepstad (2005), Hydraulic redistribution in three Amazonian trees, Oecologia, 145, 354363.

Saleska, S. R., K. Didan, A. R. Huete, and H. R. da Rocha (2007), Amazon forests green-up during 2005 drought, Science, 318, 612, doi:10.1126. 
Shuttleworth, W. J. (1988), Evaporation from Amazonian rainforest, Proc. R. Soc. London, 233, 321-346.

Sommer, R., T. D. D. Sa, K. Vielhauer, A. C. de Araujo, H. Folster, and P. L. G. Vlek (2002), Transpiration and canopy conductance of secondary vegetation in the eastern Amazon, Agric. For. Meteorol., 112, 103-121.

Souza-Filho, J. D. C., A. Ribeiro, M. H. Costa, and J. C. P. Cohen (2005), Control mechanisms of the seasonal variation of Transpiration in a northeast Amazonia tropical rainforest (in Portuguese), Acta Amazon., 35, $223-229$

von Randow, C., et al. (2004), Comparative measurements and seasonal variations in energy and carbon exchange over forest and pasture in South West Amazonia, Theor. Appl. Climatol., 78, 5-26.

Webb, E. K., G. I. Pearman, and R. Leuning (1980), Correction of the flux measurements for density effects due to heat and water vapour transfer, Q. J. R. Meteorol. Soc., 106, 85-100.

Wilson, K., et al. (2002), Energy balance closure at FLUXNET sites, Agric For. Meteorol., 113, 223-243.

P. Artaxo, Instituto de Física, Laboratório de Física Atmosférica, Rua do Matão, Travessa R 187, 05508-090 São Paulo, Brazil.
L. S. Borma, Escola de Artes, Ciências e Humanidades, Universidade de São Paulo, Rua Arlindo Béttio, 1000-Emelino Matarazzo, 03828-000 São Paulo, Brazil. (1sborma@yahoo.com.br; 1sborma@usp.br)

P. J. Brugger and D. Kurzatkowski, Laboratório de Hidrologia, Universidade Federal do Tocantins, Av. NS 15, ALCNO 14-Estação Experimental Campus de Palmas, Palmas, 77020-120 Tocantins, Brazil.

O. M. Cabral, Laboratório de Solo e Agua, Embrapa Meio Ambiente, Rodovia SP340 km 127.5, Caixa Postal 69-Jaguariuna, 13820-000 São Paulo, Brazil.

E. Collicchio, Fundação Universidade do Tocantins-UNITINS, $108 \mathrm{Sul}$ Rua 11, no. 3, Caixa Postal 173-Palmas, 77020-122 Tocantins, Brazil.

H. R. da Rocha, H. Freitas, L. Oliveira, and R. Tannus, Departamento de Ciências Atmosféricas, Universidade de São Paulo, Rua do Matão, 1226 Cidade Universitária, 05508-090 São Paulo, Brazil.

C. D. Rennó, Instituto Nacional de Pesquisas Espaciais, São José dos Campos, Av. dos Astronautas, 1758-Jardim da Granja, 12227-010 São Paulo, Brazil.

C. von Randow, Instituto Nacional de Pesquisas Espaciais, Cachoeira Paulista, Rodovia Presidente Dutra, km 40 SP/RJ, 12630-970 São Paulo, Brazil. 